Applications of Electronics to Research and Industry

A SYMPOSIUM on the applications of electronics to research and industry is being arranged by the Electronies Section of the Scientific Instrument Manufacturers' Association, to be held in the Caxton Hall, Westminster, S.W.1, during November 18 and 19. The subjects for discussion are: measurement of displacement by electronic methods ; frequency measurement ; electronics in computing; measurement of ionizing radiation; high-vacuum gauges; the radio sonde and its applications; industrial applications of ultrasonics; metal detection; electronic control of batching; electronics in spectroscopy and spectrophotometry; dynamic recording of mechanical strains; and picture telegraphy. There will be an exhibition of British electronic instruments in the Caxton Hall during the period of the meeting. Particulars and tickets of admission can be obtained on application to the Secretary.

\section{Conference on Dust in Industry}

The Society of Chemical Industry is arranging a Conference on Dust in Industry, which will be held in the University of Leeds during September 28-30. The papers are being arranged in four groups, dealing with physical characteristics and estimation of dust (chairman, Prof. H. V. A. Briscoe), practical aspects of the dust problem (chairmen, Mr. Julian M. Leonard and Mr. A. V. Hussey), fire and explosion hazards (Sir Reginald Thomas), and health hazards (Prof. E. C. Dodds). Further particulars can be obtained from the General Secretary of the Society, 56 Victoria Street, London, S.W.1.

\section{Colonial Services Appointments}

The following appointments in the Colonial Services have been announced: $R$. B. Symington, agricultural officer, Northern Rhodesia; F. W. Champion, assistant conservator of forests, Tanganyika; P. A. Daley, assistant conservator of forests, Nigeria ; D. G. Ellis, assistant conservator of forests, Nigeria; M. Gane, assistant conservator of forests, Tanganyika; G. S. MacPherson, assistant conservator of forests, Gold Coast ; H. Sanders, assistant conservator of forests, Nigeria; J. R. T. Hazell, geologist, Nigeria; C. V. Cutting, analytical chemist, Tung Experimental Station, Nyasaland; D. A. Donald (agricultural officer, Fiji), senior agxicultural officer, British Solomon Islands Protectorate; T. G. Strangeways (agricultural officer, Northern Rhodesia), senior agricultural officer, Hong Kong; W. O. Sunman (assistant to the Director of Agriculture, Kenya), assistant director of agriculture, Kenya; G. W. Chapman (assistant conservator of forests, Cyprus), senior assistant conservator of forests, Cyprus; N. Harris (geologist, Uganda), senior geologist, Uganda; W. G. Beaton (deputy director of veterinary services, Nigeria), director of veterinary services, Nigeria.

\section{The Night Sky in October}

New moon occurs on Oct. 2d. 19h. 42m., U.T., and full moon on Oct. 18d. 02h. 23m. The following conjunctions with the moon take place: Oct. 4d. $11 \mathrm{~h} .$, Mercury $4^{\circ} \mathrm{S}$. ; Oct. 5d. $18 \mathrm{~h} .$, Mars $1^{\circ}$ N. ; Oct. 8d. 02h., Jupiter $4^{\circ}$ N. ; Oct. 27 d. $17 \mathrm{~h}$. , Saturn $4^{\circ}$ S. ; Oct. 29 d. 07h., Venus $2^{\circ}$ S. ; Oct. 31d. 00h., Mercury $0.5^{\circ} \mathrm{N}$. In addition to these conjunctions with the moon, Venus is in conjunction with Regulus on Oct. 5d. 21 h., Venus $0 \cdot 4^{\circ}$ S., and on Oct. 8 d. 20 h.
Venus is in conjunction with Saturn, Venus $1 \cdot 1^{\circ} \mathrm{S}$. Mercury, in inferior conjunction on Oct. 20 and stationary on Oct. 28, is unfavourably placed for observation during the greater portion of the month. On Oct. 31 the planet rises $1 \mathrm{~h}$. $40 \mathrm{~m}$. before the sun and can be seen in the eastern sky. Venus rises at $2 \mathrm{~h}$., $2 \mathrm{~h} .40 \mathrm{~m}$. and $3 \mathrm{~h}$. $15 \mathrm{~m}$. at the beginning, middle and end of the month, respectively, and can be seen in the morning hours, stellar magnitude $-3 \cdot 6$, the visible illuminated portion of disk varying between 0.64 and 0.74 . Mars sets a little more than an hour after the sun during October and is not well placed for observation. Jupiter sets at $20 \mathrm{~h} .36 \mathrm{~m}$., $19 \mathrm{~h}$. $50 \mathrm{~m}$. and $18 \mathrm{~h} .57 \mathrm{~m}$. on Oct. 1,15 and 31 , respectively, and is visible in the western sky (stellar magnitude $-1 \cdot 6$ ) for some time after sunset. Saturn rises at $2 \mathrm{~h} .30 \mathrm{~m}$. and $0 \mathrm{~h} .50 \mathrm{~m}$. at the beginning and end of the month, and can be seen in the morning hours, stellar magnitude $0 \cdot 9$. Occultations of stars brighter than magnitude 6 are as follow: Oct. 14d. 21 h. $47 \cdot 8 \mathrm{~m} ., \psi^{3}$ Aquar. $(D)$; Oct. 2ld. 00h. 16.0m., 32 Taur. $(R)$; Oct. 25d. 03h. 47.2m., w Canc. $(R)$; $D$ and $R$ refer to disappearance and reappearance, respectively, and the latitude of Greenwich is assumed. The Orionid meteors are due about October 16-24, but moonlight will partly interfere with observation of this shower.

\section{Announcements}

Prof. M. G. Evans, professor of inorganic and physical chemistry in the University of Leeds, has been appointed to the chair of physical chemistry in the University of Manchester.

Mr. W. T. Cooper, for the past five years scientific editor and head of the Publications Department of the British Coal Utilisation Research Association, has been appointed assistant secretary (editorial) of the Institute of Fuel.

THE third Fleming Memorial Lecture of the Television Society will be delivered by Mr. Arthur Blok, who will give some personal recollections of Sir Ambrose Fleming. The Lecture will be given at the Royal Institution, London, W.1, on September 29, at 6.30 p.m.

IT is announced that, owing to lack of funds, the International Office for Nature Protection cannot continue its work in Holland, and Dr. J. H. Westermann has resigned from the post of acting director. Following the decision of the General Council, the Bureau was recently transferred from Heerengracht 540, Amsterdam, to the Royal Natural History Museum, 31 rue Fautier, Brussels, where it will be under the supervision of Prof. V. van Straelen, vicepresident of the Office.

Two courses in photoelasticity are being arranged at University College, London; one will consist of twenty-eight weekly lectures, with periods of laboratory work during the second and third terms of the session; the other, ten periods (lectures and demonstrations). Full particulars can be obtained from Col. H. T. Jessop, Photoelastic Laboratory, University College, London, W.C.1.

Erratum.-Referring to the communication entitled "A Simple Result in Quadrature" (Nature, August 7, p. 215), Sir K. S. Krishnan states that in the last entry of column 2 of the table, the numerator should read

$$
\left(2 \cos \frac{1}{2} v\right)^{\alpha+\beta-2} \exp \left\{-\frac{1}{2} i v(\alpha-\beta)\right\} \text {. }
$$

